Maja Žebčević Matić

DOI: https://dx.doi.org/10.21857/ydkx2cwpk9

Prethodno priopćenje

Rukopis prihvaćen za tisak: 21.10.2020.

\title{
TRANSFORMACIJE OBIČAJA GRGUREVA U SVJETLU NOVIH SPOZNAJA
}

\begin{abstract}
Sažetak
Grgurevo ili „Tjeranje Turaka“ jedinstveni je požeški vinogradarski običaj kojim se svake godine 12. ožujka požeški vinogradari u svojim vinogradima, pucajući iz malih topova, uz obilje vina, hrane i veselja, prisjećaju povijesnog događaja/legende prema kojoj su Požežani krajem 17. stoljeća pod vodstvom fra Luke Ibrišimovića Sokola zauvijek istjerali Osmanlije.

Promatrajući običaj od zasada pronađenog prvog pisanog spomena 1825. godine do danas, kroz spomenicu požeškoga Franjevačkog samostana, periodiku te rukopise i dnevnike možemo pratiti transformaciju njegovih elemenata uvjetovanu povijesnim i društvenim promjenama.

Posebno su drastične promjene u obilježavanju Grgureva od Drugog svjetskog rata do 90-ih godina prošlog stoljeća, tijekom kojeg je razdoblja Grgurevo preživjelo u svega nekoliko elemenata, i to zahvaljujući nekolicini vinogradara. Otada pa sve do današnjih dana Grgurevo se nastavilo obilježavati te je taj dan proglašen Danom grada uz korištenje njegovih turističkih potencijala, a drastične se promjene nastavljaju, samo u drugom smjeru.

Istraživanje na terenu otvorilo je i brojna pitanja, odnosno nove teme vezane uza sam običaj Grgureva, kojima bi se etnolozi, radi rasvjetljavanja običaja, trebali posvetiti u svojim daljnjim istraživanjima.
\end{abstract}

Ključne riječi: Požega; Grgurevo; vinogradarski običaj; transformacija običaja.

\section{Uvod}

Običaj Grgureva privukao je stručnu pažnju etnologa tek 90-ih godina 20. stoljeća. Na stručnom skupu Vinogradarska tradicija Požeško-slavonske županije održanom u Požegi 1995. godine etnologinja Gradskog muzeja Požega Maja Žebčević Matić održala je predavanje Grgurevo - požeški vinogradarski običaj. Rad je, uz ostale, tiskan sljedeće godine u Radovima hrvatskih folklorista. Terensko istraživanje provedeno tom prilikom obuhvatilo je 16 kazivača te je, uz dostupne izvore i literaturu, postalo temelj za prijedlog prema kojemu je 2007. godine običaj Grgureva upisan u Registar zaštićenih nematerijalnih dobara Republike Hrvatske. ${ }^{1}$

1 Običaj Grgureva Ministarstvo kulture Republike Hrvatske zaštitilo je kao nematerijalno kulturno dobro Republike Hrvatske pod oznakom (Z-3614) 2007. godine. 
Riječ je o običaju Grgureva koje se slavi u vinogradima 12. ožujka. Za razliku od običaja Vincelova (22. siječnja) i Martinja (11. studenog), Grgurevo je jedinstveni vinogradarski običaj Požege koji se sačuvao više od tri stotine godina zahvaljujući požeškim vinogradarima.

Njegova autohtonost počiva na povijesnom događaju (Kempf, 1910: 155) i legendi koja kaže da se 12. ožujka 1688., na dan svetog Grgura², odigrala čuvena bitka na brdu Sokolovcu kojom je grad Požega, zahvaljujući fratru Luki Ibrišimoviću Sokolu i narodu, oslobođen od osmanlijske vladavine nakon više od 150 godina.

S obzirom na to da je u prošlosti Požege na blagim padinama Požeške gore ponad grada, pa tako i na brdu Sokolovcu, većina građana radi vlastitog užitka, ali i dodatnih prihoda imala vinograde, nije čudo da su upravo vinogradari nastojali očuvati sjećanje na pobjedonosnu bitku koja je gradu donijela slobodu.

Prilikom istraživanja terena i izvora 90-ih godina ustanovljeni su sljedeći osnovni elementi Grgureva izneseni u navedenom radu:

1. Čitav običaj održava se u znak sjećanja na konačnu bitku protiv Turaka 12. ožujka 1688. pod vodstvom fra Luke Ibrišimovića Sokola;

2. Običaj se održava u vinogradima, i to samo u Požeškom vinogorju: od Vranduka do Sokolovca;

3. Sukladno tomu, običaj Grgureva obilježavaju samo vinogradari Požežani;

4. Osnova običaja jest pucanje iz mužara i topova;

5. Uz pucanje, prisutni su i vidljivi znaci veselja - pjesma, jelo i pilo (isključivo vino) (Žebčević Matić, 1996: 203).

Kako se radi o relativno mladom običaju, transformacija elemenata može se pratiti u izvorima posljednjih 200 godina. U gore navedenom radu analizirana je kao primjer promjena elemenata Grgureva vezana uz oblik prenošenja proslave običaja u Zagreb 30-ih godina 20. stoljeća zahvaljujući Klubu Požežana „Šijak“ (Žebčević Matić, 1996: 209-210).

U vrijeme spomenutog istraživanja započinjao je pak značajniji proces transformacija elemenata uzrokovan Domovinskim ratom i nacionalnim poletom koje su zahvatile običaj Grgureva krajem 20. stoljeća, na što je u navedenom radu također upozoreno (Žebčević Matić, 1996: 210).

Kako bi se dokazala dvojnost promjena elemenata, bilo je nužno nastaviti sistematsko terensko istraživanje (razgovor s kazivačima koji su sudjelovali u posljednjim promjenama) te napraviti analizu novih izvora vezanih uz običaj Grgureva, posebice nakon Drugog svjetskog rata, kada se u društveno-političkoj atmosferi u gradu nije blagonaklono doživljavala proslava običaja Grgureva.

\footnotetext{
2 Svetkovina svetog Grgura do 1969. godine (Drugi vatikanski koncil) slavila se 12. ožujka, kada je pomaknuta na 3. rujna. No to nije utjecalo na promjenu naziva ili vrijeme obilježavanja običaja.
} 
Istraživanje je nastavljeno 2019. godine sudjelovanjem etnologinje Gradskog muzeja Požega u Programu Požega, Grgurevo i tradicijsko vinogradarstvo požeškog kraja . Rezultati toga istraživanja tiskani su $\mathrm{u}$ istoimenoj publikaciji $\mathrm{u}$ radu pod nazivom Grgurevo - jedinstveni vinogradarski običaj. U spomenutom su se radu, kronološkom analizom sakupljenih podataka dijalektičkom metodom, nastojali opisati i pojasniti uzroci dosadašnjih transformacija u posljednjih gotovo 200 godina običaja Grgureva.

Razlog zbog kojeg se ovaj rad u velikoj mjeri poklapa s navedenima leži u važnosti i ozbiljnosti same teme - promjene ili transformacije elemenata zaštićenog običaja Grgureva bez stručnog nadzora. Autorica je naime imala želju i na ovome mjestu apelirati na potrebu organiziranja interdisciplinarnih istraživanja u okviru budućeg znanstveno-stručnog skupa posvećenog toj temi kako bi se postavljanjem prihvatljivih okvira budućih transformacija zaštićenog običaja Grgureva pomoglo zajednici oko njegova očuvanja.

\section{Transformacije elemenata proslave običaja Grgureva uzrokovane društveno-političkim kontekstima}

Generalno u kontekstu kronologije promjena običaj možemo pratiti od početka 19. stoljeća, odnosno od njegova do sada najstarijeg pronađenog opisa u spomenici Franjevačkog samostana u Požegi iz 1825. godine. Od sredine 19. stoljeća spomen ili opis običaja pronalazimo u požeškoj periodici (Slavonac (1863.-65.), Glasnik županije Požeške, Narod, Narodne novine, Slavonac (između dva svjetska rata), Hrvatski list, Šaljive novine, Požeški list, Požeški vodič), u nacionalnim dnevnim i tjednim novinama, u rukopisima i sjećanjima Požežana (Vidmar, Ciraki) te u izjavama kazivača sudionika u običaju.

Metodom analize podataka možemo zaključiti da je najviše promjena elemenata običaja Grgureva uzrokovano društveno-političkim okolnostima u određenim vremenskim periodima.

Naime, političke promjene koje su slavile slobodarske težnje (gašenje Bachova apsolutizma, pobjeda oporbe nad mađaronima na lokalnim izborima za Sabor početkom 20. stoljeća, vjera u Nezavisnu Državu Hrvatsku, osamostaljivanje Hrvatske 90-ih godina 20. stoljeća) svakako su utjecale i na to da Grgurevo, kao običaj koji slavi slobodu i neovisnost, dobije dodatnu vrijednost među građanima Požege i potakne cijelu zajednicu, uključujući i društveno-političke strukture, na slavlje. U tim su vremenskim razdobljima dodavani i proširivani postojeći elementi proslave obi-

\footnotetext{
Navedeni program etnologinje dr. sc. Rahele Jurković koji su financirali Ministarstvo kulture Republike Hrvatske i Grad Požega ostvaren je nizom aktivnosti u suradnji s požeškom Gimnazijom (Vesna Vlašić, Sanja Musil, Marina Farkaš), povjesničarom Goranom Hruškom, vinogradarima Ivicom Ajanovićem i Vladom Bauerom te Gradskim muzejom Požega (Maja Žebčević Matić).
} 
čaja čija se važnost u svijesti građana obično naglašavala pojačanim oduševljenjem i slobodarskim ponosom kroz vatromet ${ }^{4}$, podizanje spomenika fra Luki Ibrišimoviću Sokolu ${ }^{5}$, kićenjem i osvjetljavanjem spomenika ${ }^{6}$, svečanim misama ${ }^{7}$, kulturnim programima ${ }^{8}$, slobodnim danom za školarce ${ }^{9}$, intenzivnijim pucanjem iz mužara/ topova ${ }^{10}$. Većina takvih pomaka širila se od inicijative građana vinogradara prema aktualnoj gradskoj vlasti, koja ih je u konačnici potvrđivala i provodila.

Jednako tako, samo dijametralno suprotno, na običaj Grgureva djelovala su i vremena u kojima se gubila sloboda izražavanja i identiteta, kao primjerice za vrijeme Bachova apsolutizma, banovanja bana Raucha, Prvog svjetskog rata, Kraljevine Jugoslavije, komunizma, posebice u prva dva desetljeća nakon Drugoga svjetskog rata. U tim periodima običaj je gubio na značenju u kolektivnoj svijesti, preživio je samo dio elemenata, i to zahvaljujući krugu osviještenih vinogradara i njihovih prijatelja. ${ }^{11}$

Odmicanje od običaja, odnosno dodavanjem ili oduzimanjem njegovih elemenata, svakako je pridonosilo mijenjanju Grgureva. Stoga je jako važno, posebice s obzirom na obavezu čuvanja tog običaja kao nematerijalnog kulturnog dobra Republike Hrvatske, ne ispuštati ga iz stručnog i znanstvenog rakursa.

S obzirom na veliku količinu građe i potrebu provođenja dodatnih istraživanja, kao primjer značenja promjena za običaj Grgureva samo je pregledno naveden period od početka 30-ih do početka 90-ih godina 20. stoljeća u jednom smjeru, odnosno od početka 90-ih godina 20. stoljeća do danas u drugom.

\footnotetext{
Slavonac, 10. 3. 1863., 20. 3. 1864., 19. 3. 1865.

5 Na inicijativu franjevca Joze Kovačevića 1888. godine, u povodu 200. godišnjice održavanja bitke, osnovan je odbor za prikupljanje sredstava za spomenik fra Luki Ibrišimoviću Sokolu. Spomenik, rad mađarskog umjetnika Đure Kiša, podignut je za 5.000 forinti sakupljenih dobrovoljnim prilozima iz cijelog Hrvatskog Kraljevstva, prihodima od predstava i zabava te prilogom Grada 1893. godine na Trgu svete Terezije, ispred barokne crkve svete Terezije.

Spomenik je poslije postao mjesto prepoznavanja identiteta te se oko njega okupljaju građani prigodom Grgureva te raznih proslava.

6 Glasnik županije Požeške, 11. 3. 1899., 16. 3. 1907., 18. 3. 1911., Spomenica Franjevačkog samostana, zabilježio o. Martin Novak, 12. 3. 1906., str. 125, Glasnik županije Požeške, 15. 3. 1919., Požeške novine, 10. 3. i 17. 3. 1923., 15. 3. 1930., Požeški list, 11. 3. 1971.

7 Spomenica Franjevačkog samostana, zabilježio o. Ivo Abramović, str. 149.

8 Glasnik županije Požeške, 11. 3. 1899., Požeške novine, 10. 3. 1923., Slavonac, 24. 3. 1934., Hrvatska rieč, 11. 3. 1944., Požeške novine, 31. 3. 1988., Požeški list, 12. 3. 1992., 16. 3. 1999.

9 Spomenica Franjevačkog samostana, zabilježio o. Martin Novak, 12. 3. 1906., str. 125, zabilješka Franje Cirakija 12. 3. 1910. (Ciraki, 2004: 399).

10 Slavonac, 19. 3. 1865., Glasnik županije Požeške, 14. 3. 1903., Požeški list, 11. 3. 1971.

11 Glasnik županije Požeške, 18. 3. 1912., 15. 3. 1913., 16. 3. 1918., Požeške novine, 5. 3. 1938., Spomenica Franjevačkog samostana, 12. 3. 1947., o. Tarzicije Trstenjak, 12. 3. 1950. nepagirano, o. Kazimir Durman, nepagirano, 12. 3. 1953., nepoznati ljetopisac, nepagirano, Požeški list, 14. 3. 1957., 8. 3. 1962.
} 


\section{Kronološki pregled transformacije elemenata proslave običaja Grgureva}

Godine 1930. napisana je, a dvije godine poslije u Zagrebu je i objavljena pjesma Fra Luka Ibrišimović i vojvoda Vid Kovačević! u namjeri, kako stoji u napomeni, „da bude pristupačna najširim slojevima našeg Naroda“ te da je „u ovoj pjesmi manifestirana ljubav prema Slobodi, narodnoj Slozi i Ljubavi rodnoga kraja“ (Georgijević, 1932: 8). Uz poznatu narodnu pjesmu koja je opjevala legendarnu bitku za Požegu pod vodstvom fra Luke Ibrišimovića Sokola (Ilić Oriovčanin, 1874: 88-91), u istom stilskom izričaju napisana je dakle sasvim nova pjesma u kojoj međutim nije glavni fra Luka Ibrišimović Sokol nego vojvoda Vid Kovačević, koji je, po pjesmi, okupio „delije“ iz pravoslavnih sela ponad Požege te uz malu pomoć Ibrišimovića potjerao Turke. Činjenica da je Vid Kovačević živio gotovo 100 godina prije legendarne bitke pokazuje ${ }^{12}$ nam već na samom početku postojanja Kraljevine Jugoslavije tendenciju umanjivanja značenja centralnog lika Grgureva fra Luke Ibrišimovića, odnosno korištenja običaja stavljanjem u međunacionalni kontekst koji je nova država propagirala ${ }^{13}$.

Rezultati tih nastojanja vidljivi su desetak godina poslije. U opozicijskim klerikalnim Požěškim novinama nailazimo na tekst koji nam sugerira da se običaj Grgureva sve više zanemaruje, odnosno da gubi na svojem intenzitetu i značenju u šireoj zajednici. ${ }^{14} \mathrm{Uz}$ brojne faktore - od nadolazećeg globalizma do kulturoloških promjena - posve je jasno da je prosrpska politika u vrijeme Kraljevine Jugoslavije pridonijela tomu da se običaj Grgureva počinje zatvarati u užu vinogradarsku zajednicu bez sudjelovanja i podrške gradskih struktura i izvanjskih obilježja. Kao protuteža takvom stanju, Požežani s prebivalištem u Zagrebu okupljeni oko Šijačkog kluba, ne bez razloga, na svojoj prvoj osnivačkoj skupštini biraju upravo Grgurevo za svoju slavu $^{15}$ te ga kao dio svojeg identiteta proslavljaju u zagrebačkim vinogradima. U isto vrijeme u Budimpešti pekarski obrtnik Bogoljub Kliment na Grgurevo okuplja sve do svoje smrti 1936. godine budimpeštanske Požežane ${ }^{16}$.

Polet koji su Požežani osjetili uslijed stvaranja Nezavisne Države Hrvatske u smislu željene slobode i samostalnosti odrazio se, unatoč ratnim godinama, i na proslavi Grgureva. Tako je zabilježeno da se u jeku rata obnavlja postament spomenika fra Luki Ibrišimoviću Sokolu ${ }^{17}$ s ozbiljnim namjerama da se preseli na povoljnije mjesto $^{18}$. Na sam dan Grgureva 12. ožujka 1944. spomenik fra Luki nije mogao biti

\footnotetext{
12 Vid Kovačević narodni je hajduk koji je 1596. godine napao utvrdu Vrhovački grad i ubio vrhovačkog dizdar-agu Ismaila (Mažuran, 1977: 181).

13 Pjesma je godinu dana poslije objavljena i u projugoslavenskom požeškom tjedniku Slavonac, 11. 3. 1933.

14 Požeške novine, 5. 3. 1938.

15 Novosti, 12. 3. 1931.

16 Požeške novine, 4. 1. 1936.

17 Hrvatska rieč, 18. 12. 1943., 8. 1. 1944.

18 Hrvatska rieč, 20. 11. 1943.
} 
osvijetljen kao inače zbog mjera zamračenja, ali su ipak uz njega postavljene dvije hrvatske zastave da podsjećaju prolaznike na Grgurevo ${ }^{19}$ te je znakovito na taj dan održana godišnja skupština Vinogradarske zadruge ${ }^{20}$ (slika 1).

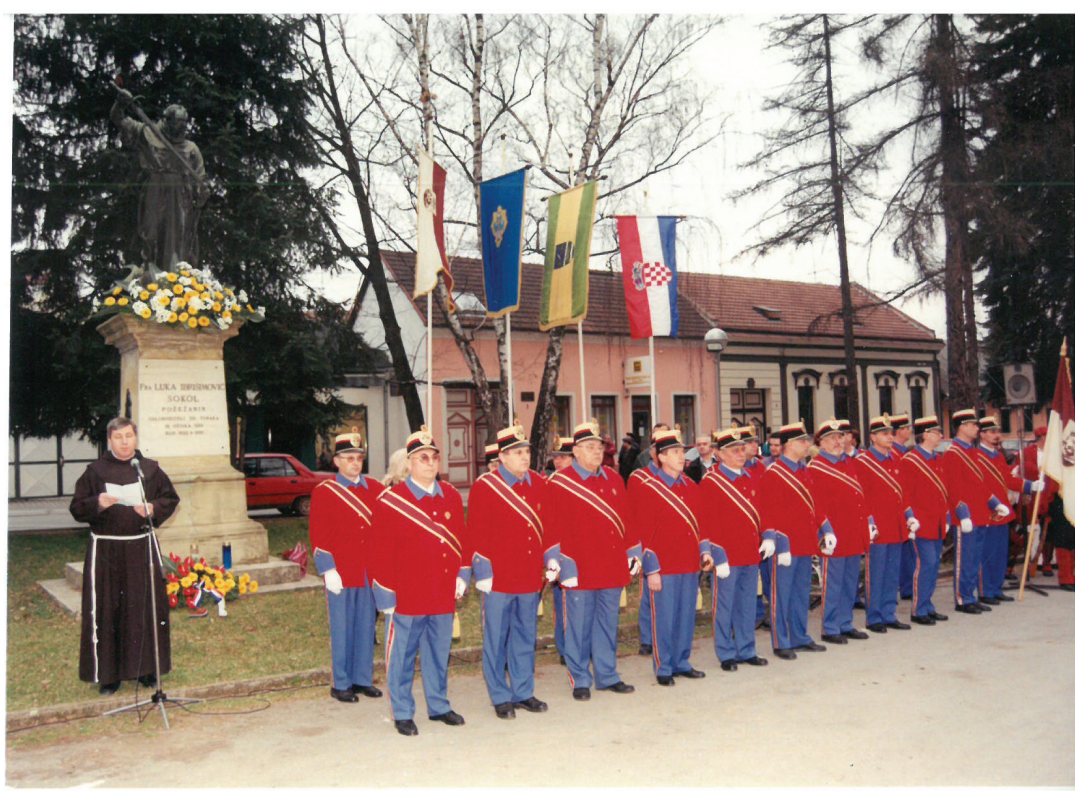

Slika 1. Postrojavanje povijesnih postrojbi ispred svečano ukrašenog spomenika fra Luki Ibrišimoviću Sokolu u Požegi za Grgurevo, 1990-ih (vlasništvo Jelene Čokrlić)

Zato je poslije Drugog svjetskog rata proslava Grgureva gotovo potpuno utihnula. Znakovito je da ni u dokumentima kao ni kod kazivača (G. Diklić, V. Dražić, I. Gašpar, B. Tancoš, K. Lončar, B. Martinčić) ${ }^{21}$ nismo zabilježili službenu zabranu proslave običaja Grgureva u tom razdoblju - zabilježene su samo policijske ophodnje po brdima na taj dan. U spomenici Franjevačkog samostana 1947. godine zabilježena je opaska kako je na Sokolovcu unatoč lijepu vremenu izostala tradicionalna proslava, odnosno da je godinu dana prije razbijena ploča na postamentu spomenika fra Luki Ibrišimoviću Sokolu uz komentar „sve hrvatsko i katoličko ima da nestane“22. Godine 1950. na dan Grgureva bio je organiziran predizborni miting, dok su uoči samog Grgureva osvanuli uvredljivi natpisi zastrašivanja po pločnicima, pa tako i ispred Franjevačkog

\footnotetext{
19 Narodna rieč, 18. 3. 1944.

20 Hrvatska rieč, 11. 3. 1944.

21 Većina kazivača kao izvor podataka korištena je u radu Maje Žebčević Matić Grgurevo jedinstveni vinogradarski običaj (2019.).

22 Spomenica Franjevačkog samostana, 12. 3. 1947., zabilježio o. Tarzicije Trstenjak, nepagirano.
} 
samostana, na kojemu je k tome ciglama razbijen i prozor na koru. ${ }^{23} \mathrm{U}$ spomenici se više ne spominje proslava Grgureva sve do 1953. godine, kada se konstatira da se Grgurevo (u svega sedam godina komunističke vlasti) gotovo zaboravilo ${ }^{24}$.

Dijelimo mišljenje kazivača (G. Diklić, I. Gašpar, B. Tancoš, R. Martinčić) koji smatraju da je promjena strukture stanovništva nakon rata, posebice onih kojih su došli na vlast i nisu znali za Grgurevo ili im ono nije ništa značilo, dovela do toga da se običaj u to vrijeme obilježavao samo po vinogradarskim kućicama u krugu prijatelja i obitelji autohtonih Požežana, ali potiho, iz straha od neprilika, bez najočitijeg elementa - simuliranja bitke s Turcima pucanjem iz topova/mužara. Zanimljiv je stoga podatak da su upravo tih 50 -ih godina kao vidljiv pokušaj da se nastavi tradicija pucanja, unatoč prešutnoj zabrani, odrasli pripremali crni barut kao i specijalno za tu prigodu napravljene metalne kutije iz kojih su onda djeca na Grgurevo pucala po brdu Sokolovcu, ponad vinograda (B. Tancoš).

U 60-im godinama 20. stoljeća običaj Grgureva više je nego ikada vezan samo za požeške vinogradare, koji ga proslavljaju u svojim vinogradima u intimnoj atmosferi druženja (I. Gašpar, K. Lončar, B. Tancoš i B. Martinčić). U to vrijeme u Požeškom listu oko 12. ožujka javljaju se tekstovi požeških intelektualaca (Potrebica, Kempf, Barbulović, Petković) koji u povijesnim tekstovima o borbi protiv Osmanlija, ne spominjući ga, diskretno skreću pozornost na običaj ${ }^{25}$. Sredinom 60 -ih godina stidljivo se upozorava na turistički potencijal legende o Grgurevu te slikovitih vinograda na požeškim obroncima uz prepoznatljivu vinogradarsku arhitekturu poput Thallerove kolibe $^{26}$. Ne bez razloga, 1968. godine Požeški se list ohrabruje i donosi čak tri članka o Grgurevu, od povijesnog članka u nastavcima tada gimnazijskog profesora povijesti Filipa Potrebice pa sve do osvrta i upozorenja da je po svemu običaj Grgureva gotovo zamro. ${ }^{27} \mathrm{U}$ želji da se obnovi sjećanje zajednice na običaj, posebno kod mlađih generacija stasalih u doba komunizma, Požeški list dvije godine poslije donosi $\mathrm{u}$ nastavcima strip o legendi vezanoj za bitku za oslobođenje grada od Osmanlija autorskog dvojca Cjetković - Njegovanović, „,Kad se digne kuka i motika“28.

Ovdje moramo spomenuti osebujnog Požežanina Miroslava Ivkovića, austrougarskog časnika koji je od završetka Prvog svjetskog rata 1918. pa sve do svoje smrti 1974. godine, dakle više od 60 godina bez obzira na službeno stajalište vlasti, za svako Grgurevo u svojem dvorištu gotovo u samom centru grada (danas Ulica Franje Tuđmana) obredno pucao iz svojega mužara. Na tom je svečanom činu

\footnotetext{
23 Isto, zabilježio ljetopisac o. Kazimir Đurman, nepagirano.

24 Isto, nepoznati ljetopisac, nepagirano.

25 Požeški list, 14. 3. 1957., 8. 3. 1962., 19. 3. 1964.

26 Požeški list, 11. 3. 1965. Prvi se put 20 godina nakon Drugog svjetskog rata u javnom glasilu spominje sam običaj Grgureva, i to kroz propitivanje njegova turističkog potencijala.

27 Požeški list, 7. 3., 21. 3. i 28. 3. 1968.

28 Požeški list, 9. 4. 1970.
} 
u duhu samog običaja okupljao brojne požeške uglednike koji su k njemu skretali prije odlaska u vinograde na proslavu Grgureva, o čemu je vodio dnevnik. ${ }^{29}$ Mužar, izliven 1912. godine, poklonio je pred sam kraj života Udruzi vinogradara i voćara „Stjepan Koydl“ koji su ga za Martinje 1974. godine krstili imenom Grga (I. Gašpar, R. i B. Martinčić). Nažalost, za jednog Grgureva prilikom ispaljivanja legendarni top raspao se na tri dijela (Ajanović, 1996: 192).

Zanos Hrvatskog proljeća 1971. godine definitivno utječe i na proslavu običaja na koji se ponovo skreće maksimalna pozornost javnosti i uključivanja zajednice, od osvjetljavanja kipa fra Luke prvi put nakon gotovo 40 godina pa sve do javnog pucanja u vinogradima prvi put nakon Drugog svjetskog rata ${ }^{30}$. Prvi koji je sa svojim radnim kolegama, poštarima na brijegu prema Sokolovcu, ispod svojeg vinograda organizirao proslavu Grgureva 1971. godine sa svim elementima, pa tako i prvi put nakon rata pucanjem iz mužara, bio je Ivan Polanc, direktor požeške Pošte koji je zbog toga godinu dana poslije prisilno umirovljen (J. Vulić).

Međutim, uslijed gušenja tog nacionalno-političkog pokreta nestaju ponovno i elementi sudjelovanja šire zajednice u obilježavanju Grgureva (kićenje spomenika fra Luki Ibrišimoviću), uključujući i praćenje običaja u Požeškom listu, ali se zato u vinogradima prvi put nakon rata nastavlja s pucanjem otvoreno i bez straha.

Štoviše, $\mathrm{u}$ duhu tog neslužbenog ohrabrenja nastaje neformalna grupa građana Društvo barutara „Fra Luka“ ili „Crni barut". Većina članova društva čak nije ni imala vinograde, ali su imali jaku slobodarsku svijest o povijesnom i običajnom značenju proslave Grgureva. U duhu druženja, pjesme i veselja priprema <istjerivanja Turaka> u vinogradima na Grgurevo, odnosno - po njima najvažnijeg elementa običaja - pucanja, trajala je tjednima. Sasvim spontano za Grgurevo godine 1979. godine Milan Grbac, član Društva barutara, od svojega je mužara (kratke željezne masivne cijevi) i drvenog postolja napravio prvi mali top nazvan Krnjo ${ }^{31}$. Od tada, prema nepisanom pravilu, među vinogradarima postaje stvar prestiža nabaviti vlastiti top i personalizirati ga posebnim imenom poput Luka, Grga, Imbro, Sokol, Caster, Gnjus, čime mužari nestaju iz upotrebe (slika 2).

Taj val ponovnog oduševljenja za proslavu Grgureva s pucanjem poklapa se sa smjenom vinogradara koji 80-ih godina 20. stoljeća kupuju zapuštene i stare vinograde s posebnom sviješću o obnavljanju tradicije proslavljanja običaja Grgureva uz što glasnije pucanje i sve veće društvo prijatelja (V. Bauer, I. Gašpar, J. Čokrlić). U to vrijeme ponovnog buđenja običaja on prestaje biti intimni obiteljski vinogradarski

29 Večernji list, 27. 4. 1972.

30 Spomenica Franjevačkog samostana, 12. 3. 1971., zabilježio o. Božidar Grđan, nepagirano, Požeški list, 11. 3. 1971 .

31 Na vrlo detaljnom opisu djelovanja Društva barutara „Fra Luka“ i proizvodnje baruta, kao i na fotografijama te zapisnicima sa sjednica društva zahvaljujem Marijanu Grpcu, koji je u posjedu prvog topa, Krnje. 
blagdan jer sve više okuplja velik broj prijatelja, uglavnom muškog društva (M. Farkaš). Odgovor tom društvenom procesu jest tzv. Žensko Grgurevo, koje se više od 20 godina održavalo u vinogradu obitelji Marine Farkaš i ima sve elemente Grgureva, samo što su organizatorice i gošće žene.

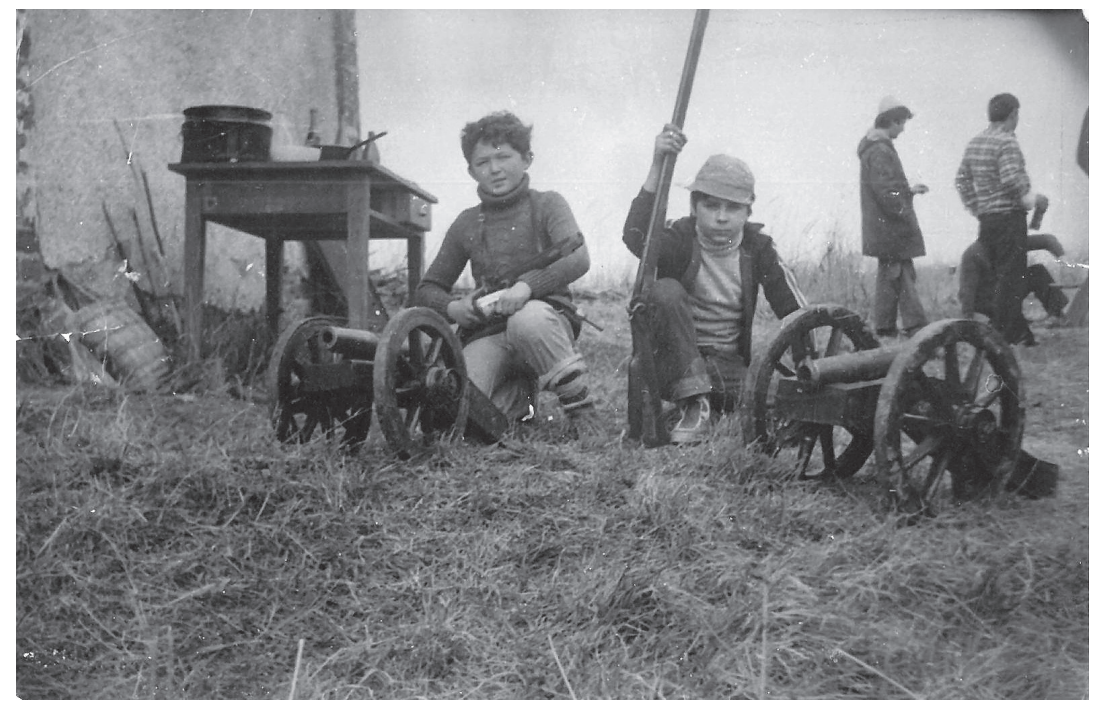

Slika 2. Prenošenje grgurevskog elementa uživljavanja tjeranja Turaka` u Društvu barutara, 12. ožujka 1979. (vlasništvo Marijana Grpca)

Osamdesete su godine, kao što vidimo, početak omasovljavanja običaja Grgureva, zbog čega se gubi vrlo važan tradicijski element vezan uz jelo, a to je vinogradarski ćevap. Vinogradarski ćevap zaboravljena je mesna poslastica koja potječe iz osmanlijskog perioda - još početkom 19. stoljeća bila je omiljena ponuda po slavonskim sajmovima. Preživjela je zahvaljujući vinogradarima zapadne Slavonije (Slatina, Pakrac, Cernik i Požega). Upravo u obliku koji danas poznajemo zadržao se među Požežanima uz običaj Grgureva sve do početka 80-ih godina (T. Vincijanović, B. Martinčić, V. Dražić), a kod nekoliko njih i poslije (I. Gašpar). Najbolji komadi dan ranije marinirane svinjetine i junetine naizmjence s lukom i slaninom nataknuti su na ražanj, umotani u potrbušnu maramicu ili masni papir i pečeni kraj otvorene vatre. Još u sedamdesetim godinama ćevap je bio zaštitni znak ne samo Grgureva nego i ostalih vinogradarskih običaja požeških vinogradara, ali se jednako tako znao naći i u ponudi kao specijalitet, recimo u Planinarskom domu Lapjak u Velikoj ${ }^{32}$. Nekada znak identiteta koji su sa sobom u svijet nosili iseljeni Požežani (B. Benković-Fleissig), pedesetak godina poslije gotovo je nestao jer naprosto nije mogao zadovoljiti

32 Vikend, 15. 6. 1979. 
sve veći broj dobrodošlih gostiju. Pripremom, količinom i kvalitetom namirnica ćevap su dakle zamijenila puno ekonomičnija jela poput čobanca ili svinjetine pečene na ražnju (Žebčević Matić, 2018: 228).

Konačno, u obilježavanje tristote obljetnice Grgureva 1988. godine, pod pritiskom javnosti, uključila se i službena politika organizacijom interdisciplinarne tematske izložbe, stručnim predavanjima i programima Vinogradarske udruge „Stjepan Koydl" poput okupljanja s topovima pred spomenikom fra Luki Ibrišimoviću ${ }^{33}$.

Uočeni potencijali proslave Grgureva sve više dovode do propitivanja javnosti na koji se sve način treba i može u običaj uključiti cijela zajednica ${ }^{34}$. Jedan od onih koji su lokalpatriotski i promišljeno poradili na promidžbi Grgureva jest vinogradar Vlado Bauer, koji već više od trideset godina u svojem vinogradu okuplja između 200 i 300 uzvanika, uglavnom viđenijih ljudi iz političkog i društvenog života Požege i Hrvatske, prenoseći im vrlo sadržajno baštinsku snagu i kulturološko značenje tog običaja. Sav trošak oko ugošćivanja tako velikog broja ljudi dijeli sa svojim sponzorima, kojima vraća uslugu kao martinjski kardinal pri ceremoniji krštenja mošta (V. Bauer).

Velik zaokret u proslavi Grgureva događa se početkom 90-ih godina 20. stoljeća. Građani, potaknuti stvaranjem hrvatske države, osjećaju da moraju skrenuti pozornost na potrebu spašavanja devastirane tradicije, pa osnivaju društvo znakovitog imena - „Društvo sveti Grgur“ (J. Čokrlić, I. Gašpar). Među osnivačima su i članovi Društva barutara „Fra Luka“, čime ono prestaje djelovati (M. Grbac, M. Roksandić).

„Društvo sveti Grgur" daje potpuno novu dimenziju običaju šireći proslavu Grgureva na nekoliko dana, uključujući u nju maksimalno zajednicu i političke strukture, što dovodi i do pokretanja procesa zaštite samog običaja kao nematerijalnog kulturnog dobra Republike Hrvatske.

Uz jačanje domoljubnog zanosa i želje za očuvanjem slobode u vrijeme Domovinskog rata, običaj Grgureva ne samo da populariziranjem ponovo postaje najjači identitet grada Požege nego se snažno omasovljuje i dobiva niz novih sadržaja. Osim što uvelike raste broj onih koji se aktivno uključuju u proslavu nabavljanjem vlastitog topa ${ }^{35}$, organiziraju se izložbe, promocije i predavanja ${ }^{36}$, znanstveni skup ${ }^{37}$ te svečane mise, uređuje se i kiti spomenik fra Luki ${ }^{38}$, zatim se na Sokolovcu, gdje je nekada bio drveni križ, postavlja 12-metarski Domovinski križ, a na šetnici prema Sokolovcu fra Lukino zvono. Jedan od idejnih inicijatora brojnih događanja uz Grgurevo jest kroničar društva dr. Željko Muljevićn ${ }^{39}$.

\footnotetext{
33 Požeški list, 17. 3. 1988.

34 Požeški list, 15. 3. 1990., 12. 9. 1992.

35 Požeški list, 10. 3. 1994.

36 Požeški list, 16. 3. 1995.

37 U listopadu 1994. godine održan je znanstveni skup Tradicijsko vinogradarstvo Požeško-slavonske županije.

38 Požeški list, 17. 3. 1994.

39 Dr. Željko Muljević vodio je dnevnik Grgureva 80-ih godina u vinogradu Slavka Harta. Dnevnik se sada nalazi u vlasništvu njegova sina Dražena Muljevića.
} 
Na temeljima tradicije pokušavaju zaživjeti novi elementi, poput ritualnog ispucavanja topa $\mathrm{u}$ podne svake nedjelje te postrojavanja povijesnih vojnih postrojbi uz pucanje topovima na javnim gradskim površinama za svako Grgurevo. Sve je veći broj sudionika događanja, ali i turista, 12. ožujka omasovljava posjet vinogradima do te mjere da narušava intimnost dotadašnje vinogradarske proslave Grgureva. Zbog pritiska nagle popularizacije običaja koja prelazi okvire društva, „Društvo sveti Grgur" 1999. godine običaj Grgureva prijedlogom želi podijeliti sa službenom politikom ${ }^{40}$, pa tako sljedeće godine Grgurevo postaje Dan grada.

Grad Požega širi proslavu Grgureva - Dana grada - brojnim kulturno-sportskim programima prije i poslije samog 12. ožujka koji nerijetko traju cijeli ožujak i mahom nisu vezani za temu Grgureva. Vrhunac proslave jest sam dan Grgureva, za kada se u 12 sati zakazuje svečana sjednica Gradske skupštine, nakon koje slijedi odlazak s gostima na proslavu običaja u vinograd. Grad Požega i Turistička zajednica grada, u želji da iskoriste turističke potencijale običaja, godinama istražuju najbolje modele proslave Grgureva. U samom gradu čine to edukativnim kostimiranim scenskim prikazima, postrojavanjem povijesnih postrojbi, smotrom topova, ritualnim ispucavanjem iz topova, prigodnim sajmom, odnosno $u$ vinogradima iznad grada nastoje približiti turistima tradicijski dio običaja. ${ }^{41}$ Time nehotice, u najboljoj namjeri, prilagođavaju pojedine elemente Grgureva turistima, odnosno gostima, poput organiziranja proslave u subotu uoči Grgureva ili nakon njega. Praksa pokazuje da se čak i dio vinogradara, zbog praktičnosti, prilagođava toj promjeni datuma, jer se konačno sav program i tenzije vezane za sudjelovanje cijele gradske zajednice u proslavi Grgureva događaju vikendom. ${ }^{42}$ Drugi dio vinogradara nastavljača tradicije smatra svetogrđem Grgurevo slaviti bilo koji drugi dan, pa i dalje, bez obzira na to što je radni dan, odlaze u svoje vinograde s prijateljima jedino 12. ožujka. No s obzirom na to da se većina njih posljednjih godina ne želi opterećivati zahtjevnim normama Zakona o eksplozivnim tvarima te proizvodnji i prometu oružja ${ }^{43}$, pucanje, odnosno uživljavanje u bitku - jedan od važnih elemenata po kojemu je Grgurevo prepoznatljivo - već nekoliko godina na taj dan izostaje.

\footnotetext{
40 Požeški list, 13. 3. 1999.

${ }^{41}$ Kako bi se zaštitili privatni obiteljski vinogradarski posjedi od sve brojnijih gostiju, isprobavani su različiti načini - od organiziranja centralnog šatora kraj kapelice svetog Vida iznad grada s poklonjenim buretom vina za sve posjetitelje do organiziranja turističke ture Hike E bike Grgurevo u kojoj za 25 kuna za čašu u tobolcu posjetitelji mogu sudjelovati u obilježavanju običaja i konzumirati ponudu hrane i vina $\mathrm{u}$ tri za to organizirana vinograda.

42 S obzirom na to da su posjetitelji dolazili svojim automobilima, kako bi se izbjegao potpuni prometni kolaps po strmim i uskim vinogradarskim putevima na kojima se obilježavalo Grgurevo od devedesetih godina naovamo, posljednjih se godina regulira promet, odnosno primjenjuje se model Hike $\mathcal{E}$ bike kojim se promiče šetnja, odnosno svladavanje destinacije brdskim biciklom.

43 Narodne novine, 70/17.
} 
Sveprisutni globalizam, promjene strukture stanovnika u gradu, posebice nakon Domovinskog rata, propitivanja političke korektnosti izraza "tjeranje Turaka“, koji je srž i konačno lokalni naziv običaja vezan uz važan elemenat tradicionalnog uživljavanja sudjelovanja u bitci za oslobođenje grada, zakonskog ograničenja glasnog pucanja, a napose sve manjeg broja vinogradara, dovodi do činjenice koju je potvrdila anketa požeških gimnazijalaca koji su 2019. godine sudjelovali u programu Požega, Grgurevo i tradicijsko vinogradarstvo požeškog kraja da je sve manje Požežana koji se poistovjećuju s običajem Grgureva, koji uopće znaju za njega, odnosno koji ga osjećaju kao svoj osobni identitet (Jurković, 2019: 31).

\section{Analiza transformacija elemenata običaja Grgureva}

Promjene običaja Grgureva možemo pratiti kroz njegove elemente koji se, uza sve ostale faktore, $u$ najvećoj mjeri prilagođavaju trenutnim društveno-političkim okolnostima. Iz svega navedenoga, kako smo rekli, ograničit ćemo se na analizu pojedinih elemenata, odnosno njihovih transformacija kroz sljedeće periode: 30-e godine 20. stoljeća za vrijeme Kraljevine Jugoslavije, 40-e godine 20. stoljeća, odnosno period Drugog svjetskog rata i Nezavisne države Hrvatske, razdoblje između 50-ih i 80-ih godina 20. stoljeća vezano uz komuniam i Socijalističku Federativnu Republiku Jugoslaviju, 90-e godine 20. stoljeća, period Domovinskog rata i stvaranja Republike Hrvatske te početak 21. stoljeća, odnosno vrijeme od kada se Grgurevo slavi kao Dan grada Požege.

\section{1. Sjećanje na legendu o istjerivanju Turaka i uživljavanje u sudjelovanje u} bitci za oslobođenje grada Požege

Možemo reći da se tijekom svih nabrojenih perioda sjećanje na bitku s Turcima prenosilo kontinuirano na nove generacije vlasnika vinograda, iako različitim intenzitetom. Posljednjih dvadeset godina sve više ulogu prenositelja i organiziranja sjećanja na bitku s Turcima ima Turistička zajednica grada Požege.

S obzirom na to da posljednjih godina sve manje vinogradara na samo Grgurevo puca iz topova, njihovo uživljavanje u bitku ostaje samo na razini sjećanja i spominjanja.

\section{2. Mjesto održavanja običaja Grgureva}

Tridesetih godina 20. stoljeća, osim u vinogradima iznad grada Požege, proslava Grgureva prenosi se u Zagreb, odnosno Budimpeštu, zahvaljujući Požežanima u dijaspori.

U samom gradu u tom periodu, osim požeških vinograda, mjesto proslave bile su i obiteljske kuće, gdje se slavlje održavalo za lošijeg vremena, odnosno nastavljalo pri silasku iz vinograda. U vrijeme 80 -ih godina 20. stoljeća proslave Grgureva 
nastavljale su se nakon odlaska iz vinograda u gostionicama, odnosno u podrumu Udruženja vinogradara.

U posljednjih nekoliko godina lokalni poduzetnik i ugostitelj čitavu proslavu Grgureva - kojoj je znalo prisustvovati više od tisuću gostiju - iz svojeg je vinograda ponad Požege, radi lakše logistike ugošćivanja, preselio u svoj ugostiteljski objekt u obližnjem selu bez vinograda.

\section{3. Nositelji održavanja običaja Grgureva}

Vidjeli smo da su proslavu Grgureva, uz Požežane vinogradare, kao dio svojeg identiteta organizirali i Požežani u dijaspori u vinogradima koji nisu njihovi. Isto su to činili i članovi Društva barutara od kojih većina nije imala svoje vinograde nego su proslavu Grgureva održavali doživljavajući je kao svoj identitet u vinogradu jednoga od njih.

Prije i nakon Drugoga svjetskog rata, kada društveno-političke strukture nisu marile za običaj, štoviše doživljavale su tradiciju obilježavanja Grgureva nepoželjnom, običaj je preživio zahvaljujući isključivo vinogradarima koji su ga slavili s uskim krugom prijatelja i obitelji.

Taj model doživljava veliku preobrazbu krajem 80-ih i početkom 90-ih godina 20. stoljeća, kada se broj gostiju povećava, odnosno kada Grgurevo u vinogradima obilježavaju uglavnom samo muškarci. Kao spontani odgovor na tu pojavu javlja se isključivo žensko Grgurevo, gdje su nositeljice običaja samo žene (M. Farkaš).

Tijekom posljednjih dvadesetak godina, uza sve manji broj vinogradara koji ponovno slave sa svojim obiteljima i prijateljima, nositelji običaja sve su više turisti, gosti, sudionici programa koje organizira Grada Požega, odnosno Turistička zajednica. ${ }^{44}$

\subsection{Pucanje}

Intenzitet vrlo važnog elementa Grgureva - neprestano pucanje od ranog jutra do kasne večeri, zaglušujuće prepucavanje s brda na brdo - varirao je od vremena do vremena, da bi u periodu od trideset godina (1941. - 1971.) gotovo sasvim zamro.

Iako se u 30-im godinama spominju i puške i kubure, najvažnije oružje - mužar - doživljava krajem 70-ih godina znakovitu transformaciju: postaje personalizirani mali top s imenom, element prestiža, posebice u 90-im godinama, kada postaje jedino sredstvo za pucanje i taj status ima do danas.

Zanimljivo je da je s pojavom Zakona o oružju kod većine vinogradara top $\mathrm{u}$ posljednjih nekoliko godina postao samo simbol slobode. Drugim riječima, suprot-

Udruga vinogradara i voćara „Stjepan Koydl“ na svojoj društvenoj mrežnoj stranici https://www.facebook.com/stjepankoydl/, predstavljajući ciljeve društva, ne spominje tradiciju obilježavanja Grgureva, iako možemo reći da su prije generacijske smjene upravo vinogradari članovi te udruge bili ti koji su spasili Grgurevo od nestajanja u drugoj polovici 20. stoljeća. 
no zaglušujućim proslavama Grgureva tijekom 90-ih, posljednjih godina topovi u vinogradima na samo Grgurevo gotovo da se i ne čuju. Puno se više čuju za vrijeme turističkog Grgureva vikend prije ili poslije (slika 3).

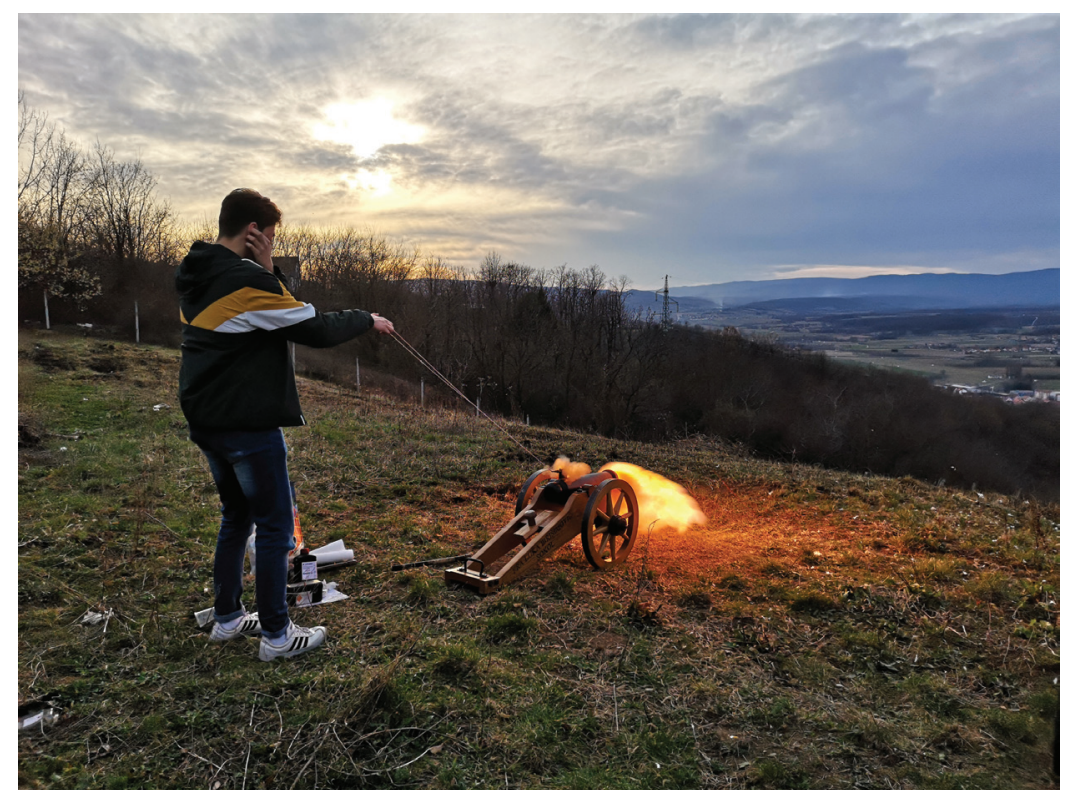

Slika 3. Pucanje iz topa u vinogradu na turističkoj proslavi Grgureva 9. ožujka 2019. (dokumentacija Gradskog muzeja Požega)

\section{6. Znaci veselja, pjesma, hrana i piće}

Sve do kasnih 80-ih godina 20. stoljeća osnova veselja na Grgurevo u vinogradima bila je pjesma te čašćenje gostiju hranom i pićem.

U prošlosti su se pjevale stare hrvatske pjesme, budnice, koje su se za vrijeme komunističkog režima kao zabranjene izvodile u kolibama iza zatvorenih vrata. Devedesetih godina 20. stoljeća natjecanju vinogradara u tome čija će proslava Grgureva biti uspješnija pridonijelo je svakako i angažiranje tamburaških sastava (K. Lončar, I. Jurković).

U vinograde su do 70-ih godina 20. stoljeća hrana i piće vinogradari nosili pješice u rukama, odnosno na leđima u naprtnjačama. Specijalitet koji se kod kuće spravljao i sirov nosio na ražnju u vinograd bio je ćevap, doista simbol građanskog staleža i želje da se dobro i izuzetno počasti obitelj i prijatelje. Vino domaćina nosilo se u pletenkama, ali se često grabilo i iz ampera koji je bilo na sredini stola dostupan svima.

Devedesetih godina, kada počinje omasovljavanje običaja, ćevap gotovo nestaje i zamjenjuje ga najčešće najekonomičnije pečeno prase s ražnja, a uz vino se pojavljuju i druga pića. 
Poznati kredo da je svatko tko taj dan navrati u vinograd dobrodošao gost s vremenom je bilo sve teže održavati, pa posljednjih godina za turiste i goste, sudionike običaja (turističkog) Grgureva, hranu i piće u samo za to predviđenim vinogradima organizatori pripremaju za simboličnu novčanu naknadu.

Istraživanje je iznjedrilo još jedan dodatni, najpromjenjiviji element Grgureva koji je po svojim transformacijama lakmus-papir društveno-političkih okolnosti:

\section{7. Značenje uključivanja cijele zajednice ${ }^{45}$ u proslavu Grgureva, odnosno isključivanja iz nje}

Iz svega do sada vidljivo je da je politička nacionalna klima određivala uključivanje društveno-političkih struktura grada u proslavu Grgureva, odnosno isključivanje iz nje. Bez obzira na okolnost je li se to činilo svjesno ili nesvjesno, to je utjecalo na popularizaciju, odnosno umanjivanje značenja običaja, a samim time na identitet grada i građana.

Isključivanjem zajednice iz proslave običaj preživljava u svojem nukleusu - požeškim vinogradima, daleko od očiju javnosti. Uključivanjem zajednice običaj se omasovljuje, te se dodaje niz sadržaja koji, ako se ponavljaju određeni niz godina, postaju i sami dio tradicije, poput kićenja spomenika fra Luki Ibrišimoviću Sokolu.

Desetljeće Kraljevine Jugoslavije, kao i nekoliko desetljeća komunističkog režima, gradske strukture nisu bile zainteresirane za sudjelovanje $\mathrm{u}$ tom običaju, pa je Grgurevo preživljavalo u zatvorenim zajednicama vinogradarskih obitelji zahvaljujući samo vrlo krhkom mehanizmu prenošenja njegovih elemenata na nove vlasnike vinograda ako vinogradi više generacija nisu ostajali u obitelji.

Od kraja 80-ih godina 20. stoljeća vidljivo je nastojanje vinogradara ne samo oko toga da se u običaj uključi cijela zajednica nego i da njegovo obilježavanje ima težinu i organizacijsku logistiku Dana grada. Time se običaju dalo na važnosti, populariziran je među građanstvom, ali i u široj javnosti dodavanjem niza sadržaja, što je formalno proslavu Grgureva proširilo na nekoliko dana. Postavlja se pitanje koliko su takvi sadržaji stihijski, a koliko stručno promišljeni, odnosno koliko opravdavaju popularizaciju običaja i jačanje identificiranja građana s njegovom tradicijom ili pak nesvjesno utječu na mijenjanje svrhe, ali i strukture običaja do njegove neprepoznatljivosti.

\section{Zaključak}

S obzirom na navedeno, smatram da bi se običaj Grgureva, nematerijalnog dobra Republike Hrvatske, trebao temeljito interdisciplinarno istražiti i na temelju do-

\footnotetext{
45 Pojam zajednica u ovom radu definiran je kao društveno-politička struktura (uprava, institucije i udruge grada) kao predstavnik svih građana, nikako sami građani.
} 
bivenih rezultata uobličiti u strategiju daljnje zaštite, odnosno niza aktivnosti koji će interpretirati i promicati običaj u samom gradu i na nacionalnoj razini tijekom cijele kalendarske godine te educirati i motivirati građane da u njemu sudjeluju sa željom identificiranja s baštinom i tradicijom grada. Jednako tako svakako treba otkloniti problem nastao zakonskom zabranom glasnog pucanja, čime se na sam dan Grgureva gubi osnovni element običaja, popularizirati među mladim obiteljima samoodrživo uzgajanje malih vinograda i pažljivo razvijati daljnji put iskorištavanja turističkih kapaciteta običaja.

Da bi se sve to postiglo, treba možda razmisliti o ideji osnivanja Ekomuzeja Grgureva u koji će, osim vinogradara i društveno-političkih struktura, biti uključeno i što više građana, nositelja običaja, ali svakako u suradnji sa strukom u želji da se naslijeđena baština Grgureva, jedinstvenog nematerijalnog kulturnog dobra Republike Hrvatske, sačuva u što izvornijem obliku za buduće generacije.

\section{Literatura}

Ajanović, Ivica (1996), Osvrt na vinogradarstvo Požeške kotline. Grgurevo - požeški vinogradarski običaj. Radovi hrvatskog društva folklorista, IV, str. 189-202.

Ciraki, Franjo (2004) Bilješke i zapisci. Požega. Društvo hrvatskih književnika, ogranak slavonsko-baranjsko-srijemski.

Georgijev, Georgije (1932), Fra Luka Ibrišimović Sokol i vojvoda Vid Kovačević!, Zagreb: privatna naklada.

Ilić Oriovčanin, Luka (1874), Lovorike Gradiškoga narodnoga graničarskoga puka br. 8 opjevaju narodne pjesme. Zagreb. str. 88-91.

Jurković, Rahela (2019), Aktivnosti provedene u okviru programa „Požega, Grgurevo i tradicijsko vinogradarstvo požeškog kraja“. Požega, Grgurevo i tradicijsko vinogradarstvo požeškog kraja, str. 28-42.

Kempf, Julije (1910), Požega zemljopisne bilješke iz okoline i prilozi za povijest slobodnog $i$ kraljeuskog grada Požege i Požeške županije. Požega.

Mažuran, Ive (1997), Požega i Požeška kotlina za turske vladavine, Požega 1277-1977, Marijan Strbašić (ur.), Slavonska Požega: Skupština općine Slavonska Požega i Odbor za proslavu 750 godišnjice grada Slavonske Požege (ur. Marijan Strbašić). Slavonska Požega, str. 161-198.

Žebčević Matić, Maja (1996), Grgurevo - požeški vinogradarski običaj. Radovi hrvatskog društva folklorista, IV, str. 203-213.

Žebčević Matić, Maja (2018), Vinogradarski ćevap, zaboravljeni požeški specijalitet s prošlošću i budućnošću. Historia Possegana Novae Themae II, str. 225-228.

Žebčević Matić, Maja (2019), Grgurevo jedinstveni vinogradarski običaj. Požega, Grgurevo i tradicijsko vinogradarstvo požeškog kraja, str 18-24. 


\section{Izvori}

Protocolium coventus Posegiansis Sancti spiritus (Spomenica Franjevačkog samostana), rkp. Str. 149-675, prijevod o. Miljenko Holtzleitner.

Konačno izvješće o radu i djelovanju odbora za podignuće spomenika fra Luki Ibrišimoviću u Požegi, inv. br 1557, Povijesna zbirka, Računalni inventarni program M++, Gradski muzej Požega (GMP).

Šijački klub u Zagrebu - hemeroteka GMP, Fa 86-11.

Požeške novine, tjedne novine, Požega.

Slavonac, tjedne novine, Požega.

Požeški list, tjedne novine, Požega.

Zakon o eksplozivnim tvarima te proizvodnji i prometu oružja, NN 70/2017. 


\section{The Transformation of the Grgurevo Custom in the Light of New Discoveries}

\section{Summary}

Grgurevo or Banishing the Turks is a unique custom from the Požega wine-growing region. Every year on 12 March, local winegrowers shoot in their vineyards from small cannons; they celebrate with homemade wine and domestic food the memory of the legend/historic event that took place in the late $17^{\text {th }}$ century, when the people from the Požega County, led by friar Luka Ibrišimović Sokol, expelled the Ottomans from their territory.

By observing this custom in the period from the first written mention thereof in 1825 to the present - through the testimonial of the Franciscan monastery, local newspapers, manuscripts and diaries - we may follow the transformation of its elements conditioned by historical and social changes.

Particularly dramatic changes of this custom occurred in the period from World War Two to the 1990s. In the course of this historical period, several elements of the Grgurevo custom survived, thanks to a few winegrowers. Since then, up to the present day, the celebration of Grgurevo has continued. 12 March has been declared the Day of the City of Požega, and the celebration thereof always includes Požega's tourism-related potentials. Drastic changes continue, yet in a different direction.

Field study has opened up many new issues and topics, which should become study material for future ethnological research regarding the illumination of the Grgurevo custom.

Keywords: Požega; Grgurevo; winegrowing custom; custom transformation.

Maja Žebčević Matić, dipl. etn., muzejska savjetnica

Gradski muzej Požega

Matice hrvatske 1, 34000 Požega

maja@gmp.hr 